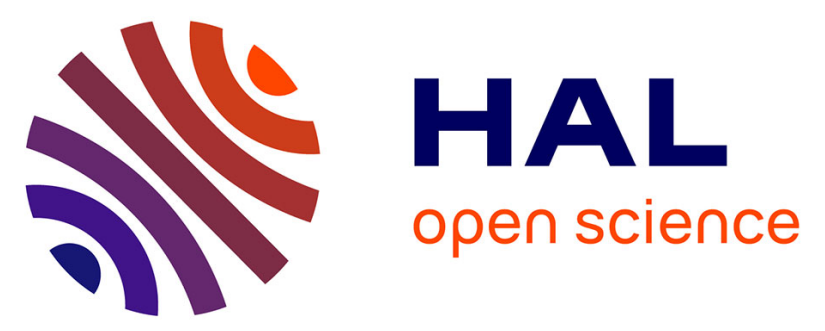

\title{
Short-term effects of daily exposure to Diesel exhaust during gestation on the olfactory system development in rabbits pups
}

Estefania Bernal Melendez, Marie-Christine Lacroix, Jacques Callebert, Didier

Durieux, Marie-Annick Persuy, Josiane Aioun, Sarah Valentino, Delphine

Rousseau-Ralliard, Anne Couturier-Tarrade, Pascale Chavatte-Palmer, et al.

\section{To cite this version:}

Estefania Bernal Melendez, Marie-Christine Lacroix, Jacques Callebert, Didier Durieux, MarieAnnick Persuy, et al.. Short-term effects of daily exposure to Diesel exhaust during gestation on the olfactory system development in rabbits pups. XIV International Congress of Toxycology, International Union of Toxicology (IUTOX) (IUTOX). Reston, USA., Oct 2016, Merida, Mexico. 10.1016/j.toxlet.2016.07.482 . hal-01870573

\section{HAL Id: hal-01870573 https://hal.science/hal-01870573}

Submitted on 5 Jun 2020

HAL is a multi-disciplinary open access archive for the deposit and dissemination of scientific research documents, whether they are published or not. The documents may come from teaching and research institutions in France or abroad, or from public or private research centers.
L'archive ouverte pluridisciplinaire HAL, est destinée au dépôt et à la diffusion de documents scientifiques de niveau recherche, publiés ou non, émanant des établissements d'enseignement et de recherche français ou étrangers, des laboratoires publics ou privés. 


\title{
Short-term effects of daily exposure to Diesel exhaust during gestation on the olfactory system development in rabbits pups
}

\author{
Bernal-Meléndez $E^{1,2}$, Lacroix $M C^{1}$, Callebert $J^{3}$, Durieux $D^{1}$, Persuy $M A^{1}$, Aioun \\ $\mathrm{J}^{4}$, Valentino, $\mathrm{S}^{4}$, Rousseau-Ralliard, $\mathrm{D}^{4}$, Tarrade $\mathrm{A}^{4}$, Chavatte-Palmer $\mathrm{P}^{4}$, \\ Schroeder $\mathrm{H}^{2}$, Baly $\mathrm{C}^{1}$, \\ ${ }^{1}$ INRA, UR1197, NBO, Univ Paris Saclay, 78350 Jouy-en-Josas, \\ France; ' 2 URAFPA, INRA UC340, Univ Lorraine, Vandœuvre-lès-Nancy, France; \\ ${ }^{3}$ Servie de Biochimie et Biologie Moléculaire, Hôpital Lariboisière, 75010, Paris, \\ France ; ${ }^{4}$ INRA, UMR BDR, INRA, ENVA, Univ Paris Saclay, Jouy-en-Josas, \\ France.
}

Introduction: Although airborne pollution is known to negatively affect the adult brain through adverse impacts on the olfactory system, the neurotoxic effects of a gestational exposure to air pollution are questioned and poorly investigated.

Objective: The present work aims to study the effects of a controlled gestational exposure to diesel exhaust (DE), at levels closely reflecting those of the urban human population, on the olfactory system development in rabbits.

Materials and Methods: Pregnant rabbits were exposed nose-only to clean air or to diluted $(1 \mathrm{mg} / \mathrm{m} 3)$ filtered DE from gestational day $3(\mathrm{GD} 3)$ to day $28,2 \mathrm{~h} / \mathrm{d}, 5 \mathrm{~d} / \mathrm{w}$. At GD28, 12 females (5 controls and 7 exposed) were sacrificed to collect fetal olfactory mucosa (OM) and bulb (OB) for anatomical and chemical measures. At postnatal day 2 (PND2), 62 control and 55 polluted pups from 18 litters (9 controls and 9 exposed) were examined for their odor-guided behavior in response to the presentation of the rabbit mammary pheromone 2-Methyl-3-butyn-2-ol (2-NBT).

Results: Electron microscopy analysis of $\mathrm{OM}$ and $\mathrm{OB}$ revealed in exposed fetuses the presence of nanosize particles $(20-48 \mathrm{~nm})$ in the olfactory sensory neurons and the glomerular layer of the $\mathrm{OB}$, along with cellular and axonal hypertrophy. $\mathrm{OB}$ of exposed animals exhibited lower levels of serotonin and higher levels of dopamine and its metabolites. Finally, the behavioral response to 2-NBT at PND2 was altered in exposed rabbits.

Conclusions: The present gestational exposure to DE affects the neuro-olfactory development of the rabbit offspring, and altered early olfactory-based behaviors. Because of the known anatomical and functional continuum between the olfactory system and the rest of the brain, such early alterations could be indicative of disturbances in higher integrative structures.

Financial Support: ANSES \& ADEME (PNR-EST 2014-1-190) 